\title{
Relationship between blood flow and steroidogenesis in the rabbit corpus luteum*
}

\author{
M. C. Wiltbank $\uparrow \uparrow$, R. C. Dysko $\ddagger \|$, K. P. Gallagher $\ddagger$ and P. L. Keyes $\uparrow \S$ \\ Departments of $\dagger$ Physiology and $\ddagger$ Surgery and $\S$ Reproductive Endocrinology Program, \\ The University of Michigan, Ann Arbor, MI 48109, U.S.A.
}

\begin{abstract}
Summary. Blood flow in the corpus luteum of the pseudopregnant rabbit was measured with tracer-labelled microspheres before and at 1 and $3 \mathrm{~h}$ after saline treatment $(\mathrm{N}=8)$ or after inhibition of progesterone synthesis with aminoglutethimide $(\mathrm{N}=10)$. Before treatment luteal blood flow $\left(29.5 \pm 3.9 \mathrm{ml} / \mathrm{min} \cdot \mathrm{g}^{-1}\right.$ (mean \pm s.e.m.) $)$ was much higher than blood flow to other tissues (ovarian stroma $=2 \cdot 9 \pm 0 \cdot 6$; uterus $=0.5 \pm 0 \cdot 1$; adrenal gland $=2 \cdot 6 \pm 0.2 \mathrm{ml} / \mathrm{min} \cdot \mathrm{g}^{-1}$ ). Aminoglutethimide reduced serum progesterone by $60 \%$ within $1 \mathrm{~h}$ but luteal blood flow was unchanged $\left(26 \cdot 2 \pm 3 \cdot 5 \mathrm{ml} / \mathrm{min} \cdot \mathrm{g}^{-1}\right)$. At $3 \mathrm{~h}$ after aminoglutethimide, serum progesterone remained low and luteal blood flow was slightly reduced to $22 \cdot 5 \pm 3.4 \mathrm{ml} / \mathrm{min} \cdot \mathrm{g}^{-1}$. This reduction was associated with a significant decline in mean arterial blood pressure which resulted in luteal vascular resistance being unaltered by aminoglutethimide treatment. Further analysis of these data indicated that serum progesterone concentration was not significantly correlated with blood flow to the corpora lutea or with blood flow to other tissues. In contrast, mean arterial blood pressure was highly correlated with blood flow to the corpus luteum $(r=0.80 ; P<0.001)$ but not to the ovarian stroma $(r=0.04)$, or adrenal gland $(r=0 \cdot 06)$. These results indicate that luteal blood flow is not acutely responsive to changes in luteal progesterone production and suggest that luteal blood flow changes passively with changes in arterial blood pressure.
\end{abstract}

Keywords: corpus luteum; ovary; blood flow; progesterone; aminoglutethimide; rabbit

\section{Introduction}

The mammalian corpus luteum has one of the highest rates of blood flow of any tissue or organ (Abdul-Karim \& Bruce, 1973; Janson \& Albrecht, 1975; Devoto et al., 1977; Ford et al., 1982), but the physiological regulation of luteal blood flow is not well understood. Because the corpus luteum produces progesterone, the hypothesis has developed that progesterone, at high concentrations, might be responsible for maintaining low vascular resistance in the corpus luteum (Ellinwood $e t$ al., 1978). Serum progesterone is positively correlated to the rate of blood flow in the ovary containing luteal tissue (Niswender et al., 1975; Ford et al., 1979; Ford \& Chenault, 1981; Janson et al., 1981; Magness et al., 1983), and progesterone treatment increases ovarian blood flow in pregnant rats (Waddell et al., 1982). These observations are consistent with the hypothesis that progesterone leads to dilatation of the ovarian and perhaps the luteal vasculature. To test this hypothesis directly, we determined the acute effect of inhibiting progesterone synthesis on blood flow and

\footnotetext{
* Reprint requests to P. L. Keyes, Department of Physiology, 7793 Medical Science II, The University of Michigan, Ann Arbor, MI 48109-0622, U.S.A.

IPresent address: Department of Physiology, Colorado State University, Fort Collins, CO 80523, U.S.A.

$\|$ Present address: Department of Comparative Medicine, Bowman Gray School of Medicine, Wake Forest University, 300 S. Hawthorne Road, Winston-Salem, NC 27103, U.S.A.
} 
vascular resistance in the corpus luteum, while simultaneously maintaining the serum concentration of the luteotrophic hormone, oestradiol-17ß (Keyes \& Nalbandov, 1967; Bill \& Keyes, 1983).

\section{Materials and Methods}

Animals and treatments. Virgin New Zealand White rabbits (Shankin Farms, MI; $2 \cdot 8-3 \cdot 4 \mathrm{~kg}$ ) were individually caged in a room with $14 \mathrm{~h}$ of light per day, at $\sim 25^{\circ} \mathrm{C}$. They were fed a daily ration of Purina rabbit chow and water was available ad libitum. All animals were injected with 40 or 50 i.u. PMSG (Sigma Chemical Co., St Louis, MO; G 4877) to ensure follicular development and 2 days later ovulation was induced by injection of 40 i.u. hCG (Sigma; CG-B). The day of injection of hCG was designated as Day 0 of pseudopregnancy. On Day I an oestradiol-filled Silastic implant (made previously in our laboratory) was inserted subcutaneously; the preparation and characteristics of these implants (3.35 $\mathrm{mm}$ i.d., $12 \mathrm{~mm}$ filled length) have been previously described (Holt et al., 1975).

Radioimmunoassay. Serum progesterone concentration was measured by radioimmunoassay using a procedure developed by Niswender (1973), and modified for measurement in rabbit serum (Holt et al., 1975). After addition of $\left[{ }^{3} \mathrm{H}\right]$ progesterone, serum was extracted with petroleum ether (mean progesterone recovery \pm s.d. $=78.7 \pm 9.9 \%$ ). The $50 \%$ binding point was $156 \mathrm{pg}$ and the intra- and interassay variability were 6 and $14 \%$ respectively.

Blood fow determination. On Day 9 of pseudopregnancy, all animals were anaesthetized by an intravenous injection of urethane (Sigma; U $2500,1.5 \mathrm{~g} / \mathrm{kg}$ ). Lidocaine was also administered intradermally at sites of incisions. For injection of microspheres, a catheter (Intramedic, PE-90; Clay Adams, Becton Dickinson \& Co., Parsippany, NJ) was inserted through the left carotid artery into the left ventricle. Correct placement of this catheter was verified by monitoring the characteristic waveform of the left ventricular pressure before and after microsphere injections. Another catheter was inserted through the right femoral artery into the abdominal aorta and this was used for the withdrawal of the reference sample and for monitoring of arterial blood pressure (with a Statham P23 Db transducer). Blood pressure was measured both before and immediately after the blood flow measurement but was not monitored during the 2-min period required to perform the microsphere injection.

Blood flow was measured with microspheres of $15 \pm 3 \mu \mathrm{m}$ diameter, labelled with cerium-141, ruthenium-103, or scandium-46 (New England Nuclear, Boston, MA), using the reference withdrawal technique (Buckberg et al., 1971; Bartrum et al., 1974; Heymann et al., 1977). Each batch of microspheres was mixed by ultrasonication for at least $30 \mathrm{~min}$ followed by vortex agitation for another $30 \mathrm{~min}$ immediately before injection. Before injection of microspheres, withdrawal of the reference blood sample was started via the catheter in the right femoral artery with a Sage withdrawal pump (model 351 ), at a continuous rate of $2.0 \mathrm{ml} / \mathrm{min}$. Approximately 300000 microspheres in $3 \mathrm{ml}$ warmed saline $(0.9 \%(\mathrm{w} / \mathrm{v}) \mathrm{NaCl})$ were infused into the left ventricle over $15 \mathrm{sec}$. The syringe and infusion catheter were then flushed twice with $3 \mathrm{ml}$ warm saline to remove residual microspheres. The withdrawal of the reference sample was continued for $1 \mathrm{~min}$ after the first saline flush and this reference blood sample was dried in scintillation vials in a desiccator oven at $65^{\circ} \mathrm{C}$. Second and third blood flow measurements were performed as described above utilizing microspheres labelled with a different radioisotope for each measurement.

At the end of the experiment, animals were killed by intraventricular injection of concentrated $\mathrm{KCl}$ and the ovaries, uterus, vagina, adrenal glands, and kidneys were removed. The corpora lutea were carefully dissected from the rest of the ovarian tissue and all tissues were stored in $10 \%$ formalin. Each tissue sample was weighed and placed in a vial for counting of radioactivity in a Tracor gamma scintillation counter (model 1185, TM Analytic, Elk Grove Village, IL). The counts per minute (c.p.m.) from the tissue samples and reference samples were corrected for background and overlap of radioactivity by simultaneous equations calculated on an Apple II plus microcomputer. Blood flow was then calculated (Heymann et al., 1977) as: tissue blood flow $(\mathrm{ml} / \mathrm{min})=$ (c.p.m. in tissue/c.p.m. in reference sample) $\times$ withdrawal rate of the reference sample $(\mathrm{ml} / \mathrm{min})$. Flow per gram of tissue $\left(\mathrm{ml} / \mathrm{min}^{-1} \mathrm{~g}^{-1}\right)$ was calculated by dividing flow by the weight of the tissue sample. The tissue vascular resistance was calculated as: tissue vascular resistance $\left(\mathrm{mmHg} / \mathrm{ml} \cdot \mathrm{min}^{-1} \cdot \mathrm{g}^{-1}\right)=$ mean arterial pressure/tissue blood flow.

General experimental protocol. On Day 9 of pseudopregnancy, rabbits were anaesthetized and an initial blood flow measurement was performed as described above. A blood sample was then obtained from the abdominal aorta for the determination of pretreatment serum progesterone concentration. The animals were then treated with one of the following: (1) an injection of $300 \mathrm{mg}$ aminoglutethimide phosphate $/ \mathrm{kg}$ body weight (Ciba-Geigy, Summit, NJ) in $10 \mathrm{ml}$ saline $(\mathrm{N}=5)$; (2) an injection of $10 \mathrm{ml}$ saline $(\mathrm{N}=4)$; (3) an injection of $300 \mathrm{mg}$ aminoglutethimide phosphate/ $\mathrm{kg}$ followed by an infusion of $150 \mathrm{mg}$ aminoglutethimide phosphate $/ \mathrm{kg} \cdot \mathrm{h}^{-1}$ for $3 \mathrm{~h}(\mathrm{~N}=5)$; (4) a saline injection and subsequent saline infusion $(N=4)$. Subsequent blood flow determinations were performed and blood samples were taken at 1 and $3 \mathrm{~h}$ after the start of treatment in all animals.

Statistics. All statistical analyses were performed using the Statview $512+$ statistics program for the Macintosh microcomputer. Differences between groups of animals were analysed by a repeated measures analysis of variance; within-animal changes in blood flow and vascular resistance during the aminoglutethimide or saline treatments were analysed by analysis variance followed by Scheffe's F1 test. The correlation coefficients (Ott, 1977) were calculated for the natural log of the tissue blood flow versus the natural $\log$ of serum progesterone concentration or mean arterial pressure. 


\section{Results}

\section{Reliability of blood flow measurements}

To document that the blood flow estimates in the corpora lutea were accurate, the number of microspheres trapped in the tissue was determined. The total luteal tissue from each animal received $\sim 24000$ microspheres, which corresponds to less than a $5 \%$ error in blood flow value due to random variability in microsphere distribution (Buckberg et al., 1971). The difference in blood flow between the right and left kidneys was used as an index of adequate microsphere mixing (Heymann et al., 1977). The correlation between blood flow to the right and left kidney was 0.98 with a regression coefficient of 1.016 (not significantly different from 1.0) and a $y$ intercept of -0.062 . The mean $( \pm$ s.e.m.) blood flow to the right and left kidney cortex was almost identical (right $=5.82 \pm 0.32 \mathrm{ml} / \mathrm{min} \cdot \mathrm{g}^{-1}$; left $=5 \cdot 77 \pm 0.33$ ). The average absolute difference between the blood flow to the right and left kidney was $7 \cdot 7 \pm 0.9 \%$ with only $2 \%$ of the values showing a difference of more than $20 \%$. Therefore, by the time the microspheres had reached the renal arteries adequate mixing had occurred.

\section{Blood flow and serum progesterone concentration}

Before saline or aminoglutethimide treatment, tissue blood flows, mean arterial pressures, and serum progesterone values were not different for the two groups of animals (Table 1). The administration of saline did not alter serum progesterone values (Table 1); in contrast, treatment with aminoglutethimide caused a marked decrease in serum progesterone at 1 and $3 \mathrm{~h}(P<0.001$; Table 1).

Table 1. Serum progesterone $\left(P_{4}\right)$, mean arterial pressure (MAP) and blood flow values at 1 and $3 \mathrm{~h}$ after aminoglutethimide (AG; $N=10$ animals) or saline $(\mathrm{N}=8)$ treatment

\begin{tabular}{|c|c|c|c|c|c|c|c|c|}
\hline & \multirow[b]{2}{*}{$\underset{(\mathrm{ng} / \mathrm{ml})}{\mathbf{P}_{4}}$} & \multirow[b]{2}{*}{$\begin{array}{c}\text { MAP } \\
(\mathrm{mmHg})\end{array}$} & \multicolumn{6}{|c|}{ Blood flow $\left(\mathrm{ml} / \mathrm{min} \cdot \mathrm{g}^{-1}\right)$} \\
\hline & & & $\begin{array}{l}\text { Corpus } \\
\text { luteum }\end{array}$ & $\begin{array}{c}\text { Ovarian } \\
\text { stroma }\end{array}$ & Uterus & Vagina & Adrenal & Kidney \\
\hline $\begin{array}{l}\text { Before } \\
\text { AG }\end{array}$ & $\begin{array}{r}34.6 \\
\pm 3.2\end{array}$ & $\begin{array}{r}76 \cdot 4 \\
\pm 5.8\end{array}$ & $\begin{array}{r}29.5 \\
\pm 3.9\end{array}$ & $\begin{array}{r}2.9 \\
+0.6\end{array}$ & $\begin{array}{r}0.5 \\
\pm 0.1\end{array}$ & $\begin{array}{r}0.5 \\
\pm 0.1\end{array}$ & $\begin{array}{r}2.6 \\
\pm 0.2\end{array}$ & $\begin{array}{r}6.8 \\
\pm 0.8\end{array}$ \\
\hline $\begin{array}{l}1 \mathrm{~h} \\
\text { after AG }\end{array}$ & $\begin{array}{c}13 \cdot 6 \\
\pm 2 \cdot 2^{*}\end{array}$ & $\begin{array}{c}69.2 \\
\pm 3.6^{*}\end{array}$ & $\begin{array}{r}26 \cdot 2 \\
\pm 3 \cdot 5\end{array}$ & $\begin{array}{r}4.5 \\
\pm 1.3\end{array}$ & $\begin{array}{r}0.6 \\
\pm 0.1\end{array}$ & $\begin{array}{r}0.4 \\
\pm 0.1\end{array}$ & $\begin{array}{r}3.5 \\
\pm 0.5\end{array}$ & $\begin{array}{r}6.4 \\
\pm 0.7\end{array}$ \\
\hline $\begin{array}{l}3 \mathrm{~h} \\
\text { after } \mathrm{AG}\end{array}$ & $\begin{array}{c}15 \cdot 7 \\
\pm 2 \cdot 2^{*}\end{array}$ & $\begin{array}{c}65 \cdot 3 \\
\pm 5 \cdot 1^{*}\end{array}$ & $\begin{array}{c}22.5 \\
\pm 3.4^{*}\end{array}$ & $\begin{array}{r}3 \cdot 2 \\
\pm 0.7\end{array}$ & $\begin{array}{r}0.5 \\
\pm 0.1\end{array}$ & $\begin{array}{c}0.2 \\
\pm 0.04^{*}\end{array}$ & $\begin{array}{r}2.6 \\
\pm 0.3\end{array}$ & $\begin{array}{c}4 \cdot 7 \\
\pm 0.5^{*}\end{array}$ \\
\hline $\begin{array}{l}\text { Before } \\
\text { saline }\end{array}$ & $\begin{array}{r}38 \cdot 7 \\
\pm 5 \cdot 3\end{array}$ & $\begin{array}{r}74.0 \\
\pm 6.3\end{array}$ & $\begin{array}{r}29.2 \\
\pm 4.4\end{array}$ & $\begin{array}{r}4.0 \\
\pm 0 \cdot 7\end{array}$ & $\begin{array}{r}0.7 \\
\pm 0.1\end{array}$ & $\begin{array}{r}0.5 \\
\pm 0.2\end{array}$ & $\begin{array}{r}2.7 \\
\pm 0.5\end{array}$ & $\begin{array}{r}6.0 \\
\pm 0.9\end{array}$ \\
\hline $\begin{array}{l}\mathrm{I} \mathrm{h} \\
\text { after saline }\end{array}$ & $\begin{array}{r}35.6 \\
\pm 2.6\end{array}$ & $\begin{array}{r}72 \cdot 0 \\
\pm 4.6\end{array}$ & $\begin{array}{r}31.8 \\
\pm 3.9\end{array}$ & $\begin{array}{c}5 \cdot 7 \\
\pm 1 \cdot 0^{*}\end{array}$ & $\begin{array}{r}0.7 \\
\pm 0.1\end{array}$ & $\begin{array}{r}0.4 \\
\pm 0.1\end{array}$ & $\begin{array}{r}3.4 \\
\pm 0.7\end{array}$ & $\begin{array}{r}5.9 \\
\pm 0.8\end{array}$ \\
\hline $\begin{array}{l}3 \mathrm{~h} \\
\text { after saline }\end{array}$ & $\begin{array}{r}38.4 \\
\pm 6.8\end{array}$ & $\begin{array}{r}66 \cdot 3 \\
\pm 7 \cdot 3\end{array}$ & $\begin{array}{r}26 \cdot 5 \\
\pm 6 \cdot 2\end{array}$ & $\begin{array}{r}4 \cdot 1 \\
\pm 1 \cdot 2\end{array}$ & $\begin{array}{r}0.6 \\
\pm 0.2\end{array}$ & $\begin{array}{r}0.3 \\
\pm 0.1\end{array}$ & $\begin{array}{r}2.4 \\
\pm 0.4\end{array}$ & $\begin{array}{c}3.9 \\
\pm 0.8^{*}\end{array}$ \\
\hline
\end{tabular}

$* P<0.05$ compared with pretreatment value.

Values are mean \pm s.e.m.

Since blood flows and other measures were the same in animals treated by injection or infusion of saline, the data were pooled. Saline treatment had no significant effect on mean arterial pressure or blood flow to the corpus luteum, which remained at high levels at 1 and $3 \mathrm{~h}$ (Table 1). Significant changes were observed in ovarian blood flow at $1 \mathrm{~h}$ of saline administration, and in kidney blood flow at $3 \mathrm{~h}$ (Table 1). 
Table 2. Correlation coefficients for natural $\log (\ln )$ of serum progesterone concentration or mean arterial blood pressure versus tissue blood flow ( $n=54$ measurements in 18 rabbits)

\begin{tabular}{|c|c|c|c|c|c|c|}
\hline & \multicolumn{6}{|c|}{ ln Blood flow (ml/min'g) } \\
\hline & $\begin{array}{l}\text { Corpus } \\
\text { luteum }\end{array}$ & $\begin{array}{l}\text { Ovarian } \\
\text { stroma }\end{array}$ & Uterus & Vagina & Adrenal & Kidney \\
\hline $\begin{array}{l}\text { In Serum } \\
\text { progesterone } \\
\text { conc. (ng/ml) }\end{array}$ & 0.01 & 0.17 & 0.08 & $0 \cdot 10$ & $0 \cdot 17$ & $0 \cdot 06$ \\
\hline $\begin{array}{l}\text { In Mean arterial } \\
\text { pressure (mmHg) }\end{array}$ & $0 \cdot 80^{*}$ & 0.04 & $0.61^{*}$ & $0.58^{*}$ & 0.06 & $0.63^{*}$ \\
\hline
\end{tabular}

Blood flow and other measures were the same in animals treated by injection or infusion of aminoglutethimide and, therefore, the data were pooled. Aminoglutethimide treatment was accompanied by small, but significant, reductions in mean arterial pressures (Table 1). At $1 \mathrm{~h}$ there was no significant change in blood flow to the corpus luteum, but at $3 \mathrm{~h}$ the decreased mean arterial blood pressure was associated with a significant reduction in blood flow to the corpus luteum as well as to the vagina and kidneys (Table 1). Despite the diminution of blood flow to these organs, vascular resistance, which is the critical measure of vascular control, was unchanged and was not different from that in saline-treated animals (Fig. 1). Progesterone production was therefore reduced with aminoglutethimide, but this was not associated with significant alteration in vascular resistance of the corpus luteum.

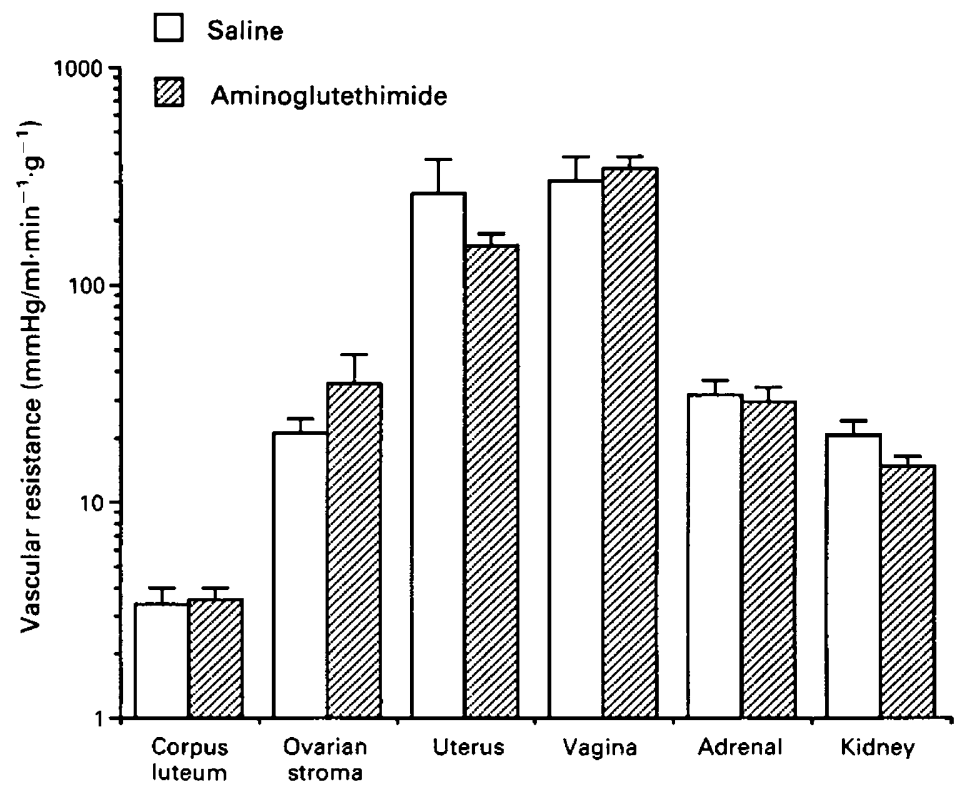

Fig. 1. Effect of $3 \mathrm{~h}$ of aminoglutethimide $(\mathrm{N}=10$ animals $)$ or saline $(\mathrm{N}=8)$ treatment on tissue vascular resistance. Mean \pm standard error of the mean.

The low vascular resistance in the corpus luteum, relative to that in other tissues (Fig. 1), was reflected in the high rate of luteal blood flow which was 10 -fold greater than ovarian stromal blood 
flow, 50-fold greater than uterine blood flow, 75-fold greater than vaginal blood flow, 10-fold greater than adrenal gland blood flow, and 4-fold greater than kidney blood flow (Table 1).

Table 2 shows that there was no significant correlation between serum progesterone concentration and blood flow to any of the tissues. In contrast, mean arterial pressure was significantly correlated with blood flow to the corpus luteum $(y=-3.94+1.68 x)$, uterus $(y=-7.25+$ $1 \cdot 54 x)$, vagina $(y=-8.54+1 \cdot 72 x)$ and kidney $(y=-3.32+1 \cdot 17 x$; all values are for the natural $\log$ of the variable), whereas no significant correlation was observed between mean arterial pressure and blood flow to the ovarian stromal tissue or to the adrenal gland (Table 2).

\section{Discussion}

As reported previously (Abdul-Karim \& Bruce, 1973; Janson \& Albrecht, 1975; Devoto et al., 1977), and confirmed here, the corpus luteum has a very high rate of blood flow. This high rate of blood flow suggests that the blood vessels of the corpus luteum exert a low resistance to blood flow. The objective of this study was to determine whether progesterone or other steroids might be responsible for maintaining a low vascular resistance in the corpus luteum. Progesterone has been shown to cause changes that are consistent with a role as a vasodilator: progesterone treatment increases ovarian blood flow in pregnant rats (Waddell et al., 1982); progesterone decreases the contractile activity of myometrial (Allen \& Reynolds, 1935) and gastrointestinal (Gill et al., 1985) smooth muscle; progesterone pellets placed in the uterine horn cause an increase in the diameter of the ovarian and uterine vein in ovariectomized mice (Forbes \& Glassen, 1972); and progesterone modifies the responsiveness of blood vessels to vasoactive agents (Orosz et al., 1983; Skoog \& Kenney, 1983). The inhibition of progesterone production by aminoglutethimide, however, did not change vascular resistance within the corpus luteum. The slight fall in luteal blood flow during aminoglutethimide treatment (Table 1) cannot be attributed to a direct effect of aminoglutethimide within the corpus luteum, because of the concomitant decline in mean arterial pressure in this group. Blood flow to the corpus luteum correlates closely with alterations in mean arterial pressure (Table 2), suggesting that the corpus luteum is operating on a linear pressure-flow curve.

Aminoglutethimide inhibits steroidogenesis by competing with cholesterol for the binding site on the mitochondrial P-450 enzyme that is responsible for cleaving the cholesterol side-chain (Uzgiris et al., 1977; Simpson, 1979). Our results indicate that aminoglutethimide caused a $60 \%$ reduction in peripheral serum concentrations of progesterone within $\mathrm{I} \mathrm{h}$, and that this reduction was still present at $3 \mathrm{~h}$. This interval was chosen as a reasonable period to expect a change in vascular resistance since oestradiol-17\% causes vasodilatation of the uterine vasculature within $30 \mathrm{~min}$ and has maximal effects by $2-3 \mathrm{~h}$ (for review see Meschia, 1983). Despite a marked decline in luteal progesterone production, the vascular resistance within the corpus luteum was not altered by the aminoglutethimide treatment. This finding leads to our main conclusion that vascular resistance in the corpus luteum is not acutely dependent upon the normal rates of luteal progesterone production at this stage of pseudopregnancy.

In other studies, serum progesterone concentration, and luteal or ovarian blood flow were significantly correlated (Niswender et al., 1975, 1976; Ford et al., 1979; Ford \& Chenault, 1981; Janson et al., 1981; Magness et al., 1983), an observation that at first glance seems contradictory to the results reported here. However, these correlations were made throughout the entire luteal phase and include the effects of marked structural changes that occur in the luteal vasculature. The luteal vasculature is formed initially by multiplication and invasion of the thecal capillaries (for review see Findlay, 1986), leading to increased blood flow in the developing corpus luteum, which also has increased steroidogenic capacity. At the end of the luteal phase, in most species, luteal blood flow declines as serum progesterone values fall (Bruce \& Moor, 1976; Niswender et al., 1976; Devoto et al., 1977; Wehrenberg et al., 1978; Ford et al., 1979; Hossain et al., 1979; Magness et al., 
1983). Again this change in luteal blood flow is associated with structural changes in the vasculature, since the number of luteal endothelial cells declines during luteolysis (Niswender et al., 1976; Azmi et al., 1984; Farin et al., 1986). Therefore, the lack of a correlation between serum progesterone concentration and luteal blood flow, in our experiments and in experiments of others (Bruce et al., 1980; Bruce \& Meyer, 1981), can be explained on the grounds that an experimental period of several hours is insufficient to observe structural changes in luteal blood vessels. It is also possible that a correlation between luteal progesterone production and luteal blood flow could not be detected because the measurement of peripheral serum progesterone concentration did not accurately reflect luteal progesterone production. However, if the half-life of progesterone was not altered (an assumption not verified in this study), then during a 3-h time period peripheral progesterone concentration should reflect luteal progesterone production.

If blood flow is not altered by acute changes in progesterone synthesis, what other hormones might affect blood flow? Oestradiol is a possible candidate, since this hormone is the primary luteotrophic hormone in the rabbit (Keyes \& Nalbandov, 1967; Bill \& Keyes, 1983) and has been shown to increase ovarian blood flow in sheep (Rosenfeld, 1980). In the present experiments, oestradiol was administered continuously in order to ensure that any observed changes in blood flow were not attributable to diminished availability of oestrogen. In a separate study (Wiltbank, 1987) we have found that neither oestradiol nor human chorionic gonadotrophin (hCG) alter luteal blood flow, despite marked changes in steroidogenesis induced by these hormones. Similar results have been reported by Norjavaara et al. (1987), who observed that the injection of LH or hCG did not produce an increase in blood flow to the rat corpus luteum. Based upon such observations, we have no compelling evidence that either progesterone or luteotrophic hormones acutely regulate blood flow in the corpus luteum.

The significant positive correlation between mean arterial pressure and luteal blood flow may offer some insight into the control of luteal blood flow. By calculating the coefficient of determination or $R^{2}$ (Ott, 1977), 65\% of the variation in blood flow to the corpus luteum can be explained by variation in mean arterial pressure, whereas in other tissues, $<40 \%$ of the variation is attributable to changes in mean arterial pressure. Other investigators have also reported a positive correlation between mean arterial pressure and luteal blood flow in anaesthetized rabbits (Janson \& Albrecht, 1975; Janson et al., 1981) and rats (Selstam et al., 1985). At variance with the above, is a report by Bruce \& Gibbs (1976) who observed a negative correlation between mean arterial pressure and luteal blood flow $(r=-0.425)$ in unanaesthetized pregnant rabbits. However, these investigators observed that the unanaesthetized rabbits "were hyperventilating ... [possibly] due to anxiety and disturbance of their catecholamine levels" (Bruce \& Gibbs, 1976). An elevation in catecholamine concentrations could change the relationship between mean arterial pressure and luteal blood flow: catecholamines may increase mean arterial pressure but potentially decrease luteal blood flow (Selstam et al., 1985; M. C. Wiltbank, K. P. Gallagher \& P. L. Keyes, unpublished results).

In conclusion, the lack of responsiveness of the luteal vasculature to changes in hormonal milieu, and the positive correlation between blood flow and mean arterial pressure, suggest that the luteal vascular system is operating on a linear pressure-flow curve with a very low vascular resistance. The basis of low vascular resistance appears to be related to structural elements in the corpus luteum, such as high capillary density and lack of muscular arterioles (Dharmarajan et al., 1985; Wiltbank, 1987) rather than to hormonal factors. This view is consistent with our knowledge of the luteal vasculature, which appears to consist of sinusoidal capillaries (Sobotta, 1897; Dharmarajan et al., 1985), and which lacks autonomic nerves (Burden, 1972; Unsicker, 1974) or vascular smooth muscle (Wiltbank, 1987).

This work was supported by NIH grants HD-07127 (P.L.K.), P30-HD-18258, HL-32043 (K.P.G.), NIH Training Grant HD-07048 (M.C.W.), and NIH Career Development Award HL-04120 (K.P.G.). 


\section{References}

Abdul-Karim, R.W. \& Bruce, N. (1973) Blood flow to the ovary and corpus luteum at different stages of gestation in the rabbit. Fert. Steril. 24, 44-47.

Allen, W.M. \& Reynolds, N.W. (1935) Physiology of the corpus luteum. $X$. The comparative actions of crystalline progestin and crude progestin on uterine motility in unanesthetized rabbits. Am. J. Obstet. Gynec. 30, 309-317.

Azmi, T.I., O'Shea, J.D., Bruce, N.W. \& Rodgers, R.J. (1984) Morphometry of the functional and regressing corpus luteum of the guinea pig. Anat. Rec. 210, $33-40$.

Bartrum, R.J., Jr, Berkowitz, M. \& Hollenberg N.K. (1974) A simple radioactive microsphere method for measuring regional flow and cardiac output. Invest. Radiol. 9, 126-132.

Bill, C.H., III \& Keyes, P.L. (1983) I7 $\beta$-Estradiol maintains normal function of corpora lutea throughout pseudopregnancy in hypophysectomized rabbits. Biol. Reprod. 28, 608-617.

Bruce, N.W. \& Gibbs, C.P. (1976) Ovarian blood flow in conscious and anaesthetized pregnant rabbits near term and the influence of arterial blood gas tensions. J. Reprod. Fert. 47, 343-345.

Bruce, N.W. \& Meyer, G.T. (1981) Ovarian blood flow and progesterone secretion in anaesthetized rats at Day 16 of gestation, and the effects of haemorrhage. J. Reprod. Fert. 61, 419-423.

Bruce, N.W., Meyer, G.T. \& Dimmitt, S.B. (1980) Progesterone secretion and ovarian blood flow in the pregnant rat. J. Endocr. 85, 327-330.

Bruce, N.W. \& Moor, R.M. (1976) Capillary blood flow to ovarian follicles, stroma and corpora lutea of anaesthetized sheep. J. Reprod. Fert. 46, 299-304.

Buckberg, G.D., Luck, J.C., Payne, D.B., Hofiman, J.I.E., Archie, J.B. \& Fixler, D.E. (1971) Some sources of error in measuring regional blood flow with radioactive microspheres. J. appl. Physiol. 31, 598-604.

Burden, H.W. (1972) Adrenergic innervation in ovaries of the rat and guinea pig. Am. J. Anat. 133, 455-462.

Devoto, L., Blasco, L., Flickinger, G.L., Wu, C.H. \& Mikhail, G. (1977) Search for arteriovenous shunts in the genital tract of the pseudopregnant rabbit. Proc. Soc. exp. Biol. Med. 155, 369 372.

Dharmarajan, A.M., Bruce, N.W. \& Meyer, G.T. (1985) Quantitative ultrastructural characteristics relating to transport between luteal cell cytoplasm and blood in the corpus luteum of the pregnant rat. Am.J. Anat. 172, 87-99.

Ellinwood, W.E., Nett, T.M. \& Niswender, G.D. (1978) Ovarian vasculature: Structure and function. In The Vertebrate Gonad, pp. 583-614. Ed. R. E. Jones. Plenum Publishers, New York.

Farin, C.E., Moeller, C.L., Sawyer, H.R., Gamboni, F. \& Niswender, G.D. (1986) Morphometric analysis of cell types in the ovine corpus luteum throughout the estrous cycle. Biol. Reprod. 35, 1299-1308.

Findlay, J.K. (1986) Angiogenesis in reproductive tissues. J. Endocr. 111, 357-366.

Forbes, T.R. \& Glassen, G. (1972) Steroid compounds and the dilatation of ovarian and uterine veins in the mouse. Am. J. Obstet. Gynecol. 113, 678-680.
Ford, S.P. \& Chenault, J.R. (1981) Blood flow to the corpus luteum-bearing ovary and ipsilateral uterine horn of cows during the oestrous cycle and early pregnancy. J. Reprod. Fert. 62, 555-562.

Ford, S.P., Christenson, R.K. \& Chenault, J.R. (1979) Patterns of blood flow to the uterus and ovaries of ewes during the period of luteal regression. J. Anim. Sci. 49, 1510-1516.

Ford, S.P., Reynolds L.P. \& Magness R.R. (1982) Blood flow to the uterine and ovarian vascular beds of gilts during the estrous cycle and early pregnancy. Biol. Reprod. 27, 878-885.

Gill, R.C., Bowes, K.L. \& Kingma, Y.J. (1985) Effect of progesterone on canine colonic smooth muscle. Gastroenterology 88, 1941-1947.

Heymann, M.A., Payne, B.D., Hofman, J.I.E. \& Rudolph, A.M. (1977) Blood flow measurements with radionuclide-labeled particles. Prog. Cardiov. Dis. 20, 55-79.

Holt, J.A., Keyes, P.L., Brown, J.M. \& Miller, J.B. (1975) Premature regression of corpora lutea in pseudopregnant rabbits following the removal of polydimethylsiloxane capsules containing $17 \beta$-estradiol. Endocrinology 97, 76-82.

Hossain M.I., Lee C.S., Clarke, I.J. \& O'Shea, J.D. (1979) Ovarian and luteal blood flow, and peripheral plasma progesterone levels, in cyclic guinea-pigs. $J$. Reprod. Fert. 57, 167-174.

Janson, P.O. \& Albrecht, I. (1975) Methodological aspects of blood flow measurement in ovaries containing corpora lutea. J. appl. Physiol. 38, 288-293.

Janson, P.O., Damber, J.-E. \& Axen, C. (1981) Luteal blood flow and progesterone secretion in pseudopregnant rabbits. J. Reprod. Fert. 63, 491-497.

Keyes, P.L. \& Nalbandov, A.V. (1967) Maintenance and function of corpora lutea in rabbits depend on estrogen. Endocrinology 80, 938-946.

Magness, R.R., Christenson, R.K. \& Ford, S.P. (1983) Ovarian blood flow throughout the estrous cycle and early pregnancy in sows. Biol. Reprod. 28, 1090 1096.

Meschia, G. (1983) Circulation to female reproductive organs. In Handbook of Physiology, Section 2, The Cardiovascular System, vol. III, The Peripheral Circulation, part I, pp. 241-269. Eds J. T. Shepherd \& R. M. Abbond. American Physiological Society, Bethesda, MD.

Niswender, G.D. (1973) Infiuence of the site of conjugation on the specificity of antibodies to progesterone. Steroids 22, 413-426.

Niswender, G.D., Moore, R.T., Akbar, A.M., Nett, T.M. \& Diekman, M.A. (1975) Flow of blood to the ovaries of ewes throughout the estrous cycle. Biol. Reprod. 13, 381-388.

Niswender, G.D., Reimers, T.J., Diekman, M.A. \& Nett, T.M. (1976) Blood flow: a mediator of ovarian function. Biol. Reprod. 14, 64-81.

Norjavaara, E., Olofsson, J., Gafvels, M. \& Selstam, G. (1987) Redistribution of ovarian blood flow after injection of human chorionic gonadotropin and luteinizing hormone in the adult pseudopregnant rat. Endocrinology 120, 107-114. 
Orosz, M., Csapo, I. \& Varga, B. (1983) Alteration in the reactivity of hamster cheek pouch arterioles to prostaglandin $\mathrm{E}_{2}$ and noradrenaline during pregnancy or sex steroid treatment. Prostaglandins 26, 165-171.

Ott, L. (1977) An Introduction to Statistical Methods and Data Analysis, pp. 218-229. Wadsworth Publishing, Belmont.

Rosenfeld, C.R. (1980) Responses of reproductive and nonreproductive tissues to $17 \beta$-estradiol during ovine puerperium. Am. J. Physiol 239, E333-E339.

Skoog, K.M. \& Kenney, N.J. (1983) Pressor responses to central angiotensin II, prostaglandin $E_{1}$ and prostaglandin $\mathrm{E}_{2}$ : effect of ovarian steroids. Neuroendocrinology 36, 144-151.

Selstam, G., Gafvels, M., Norjavaara, E. \& Damber, J.-E. (1985) Acute increase of noradrenaline on vascular resistance in the corpus luteum of the pseudopregnant rat. J. Reprod. Fert. 75, 351-356.

Simpson, E.R. (1979) Cholesterol side-chain cleavage, cytochrome P-450, and the control of steroidogenesis. Molec. cell. Endocrinol. 13, 213-221.
Sobotta, J. (1897) Über die bildung des corpus luteum beim kaninchen. Anat. Hefte 8, 469-520.

Unsicker, K. (1974) Qualitative and quantitative studies on the innervation of the corpus luteum of rat and pig. Cell Tissue Res. 152, 513-524.

Uzgiris, V.I., Whipple, C.A. \& Salhanick, H.W. (1977) Stereoselective inhibition of cholesterol side chain cleavage by enantiomers of aminoglutethimide. Endocrinology 101, 89 96.

Waddell, B.J., Bruce, N.W. \& Olynyk, J.K. (1982) Independence of ovarian progesterone secretion rate from arterial progesterone concentrations in the pregnant rat. $J$. Endocr. 94, 61-67.

Wehrenberg, W.B., Dierschke, D.J., Rankin, J.H.G. \& Wolf, R.C. (1978) Variations in "functional" blood flow as related to corpus luteum activity in cyclic guinea pigs. Biol. Reprod. 19, 380-384.

Wiltbank, M.C. (1987) Regulation of blood flow to the rabbit corpus luteum. Ph.D. thesis, University of Michigan.

Received 25 February 1988 